\title{
THE ROLE OF NATURE IN CREATING MYSTERY AND TERROR IN THE SHORT STORIES OF RUSKIN BOND, WITH SPECIAL REFERENCE TO LISTEN TO THE WIND AND THE WIND ON HAUNTED HILL
} SAPTORSHI DAS \& ISA MISHRA

Kalinga Institute of Industrial Technology School of Management, Bhubaneswar, Odisha, India

Nature and Ruskin Bond are inextricably bound. His stories abound in the most adorable and charmingly, intriguingly memorable characters whose magic refuse to fade away with time. Yet, nature is what we always talk of when we talk Bond. The aura that nature creates in his stories to take the narrative forward, the role it plays in shaping the lives and destinies of his characters, the sheer, mesmerizing beauty lying in it, or the ominous terrors in its darkest depths, nature is a dominant force, a powerful presence in his short stories. This paper reflects Bond's love for the literary depiction of nature through two of his well known and widely read short stories: Listen to the Wind, and The Wind on Haunted Hill. And in these two stories, he relates nature to one of the most talked about, read about and searched about interests of man, the supernatural, and through the use of supernatural elements keeps the attention of the reader revetted right till the end. The master of story-telling is at his best in these two tales, and none can match up to his kind of creative excellence and his passionate zeal for the myriad faces of nature.

KEYWORDS: Hills, Wind, Cold \& Haunted
\end{abstract}

Received: Jun 21, 2018; Accepted: Jul 12, 2018; Published: Jul 28, 2018; Paper Id.: IJELAUG20183

\section{INTRODUCTION}

The Role of Nature in Creating Mystery and Terror in the Short

Stories of Ruskin Bond, with Special Reference to Listen to

the Wind and the Wind on Haunted Hill

What is it that makes us feel so free and liberated standing amidst lush greenery with the clear blue sky above us? What is that feeling of sheer independence like there are no shackles binding us? Like we have no confinements, no rules, no regulations to adhere to... Like we are not bound in social chains or are a part of a cat race we continuously try to master and win... What is it that makes us gaze at the horizon with the sand crushed beneath our feet on a sun-lit sea shore and envy the endlessness of that distant blue line, wishing wistfully that so was our life with our loved ones? What is it that makes us reflect on the frothy blue waves crashing against the shore and receding back into the calmer oceans farther away, comparing them to the waves of sorrow and pain that crash into our lives and gently recede into the past with time? The gurgling laughter in cascading waterfalls, the mystique of white, foggy mists, the music of the pitter-patter of raindrops on the sun-parched earth... all those myriad aspects of nature that make us feel that there is still some beauty left in this world, a world torn apart by wars and discrimination from man to man, a world ravaged by unthinkable crimes and misdeeds, a world that is desperate to see the light of such a day when only peace and fraternity abound. 
What is it about nature that strikes a chord deep within us? Most of us are too wrapped up in our mundane daily lives to pay a heed to it. But it is there. When we take a deep breath sometimes in the midst of work, it is that chord that gives that feeling of rest, transitory though it is but rests nonetheless. Rain, snow, rainbow, birds.... All so beautiful, Most of us take it for granted. But there are still those who are deeply grateful to nature for all its beauties and bounties, whose are inextricably bound to them and share an inseparable bond with them. Ruskin Bond is one of the latter kind and this paper highlights how this master of story-telling employs nature and its myriad faces to create a perfectly conducive environment to take his stories further, towards an intriguing and thought-provoking end. In this paper nature and its role is explored with reference to two of his very well-known stories - Listen to the Wind and The Wind on Haunted Hill.

Ruskin Bond loved writing for children and is known to be a pioneer of children literature in India. Bond's worship of childhood is greatly influenced by his reading of the Indian and British Romantic writers, the uncomplicated poetry of Rabindranath Tagore, the simplicity of life portrayed by Raja Rao, R. K. Narayan, and Mulk Raj Anand, and an earnest reflection of Indian childhood in many works of Sudhin Goshe. His short stories are not just about nature but also dedicated to and extol the virtues of the simplest, purest, truest facet of nature - childhood. His stories for children help them find in nature the peace and calm and love that in the later years of adulthood would slowly recede into the remotest corners of their consciousness. These stories feature every aspect of nature - from harmless and adorable pets to wild tigers, leopards, bears, and even ghosts - written in his inimitable witty style. And in the two stories referred to in this paper, Bond relates nature to the supernatural in Listen to the Wind, and The Wind on Haunted Hill.

Listen to the Wind, featuring in Bond's collection of short stories, Rusty Comes Home, reflects Bond's passionate interest in the divine beauty of the hills of Mussoorie, and his love for the mysteries lurking in the shadows of Pari Tibba, the hill where the narrator resides.

The story begins on the hills in the month of March - a time of gloom - the heavy rain and cold a foreboding of the melancholy to unfold. Thundershowers and lightning add to its unpleasantness. Life is difficult. Chily wind, cold rain, sleet, and hail, tear through the hills with ferocious force. Temperatures dip, people huddle before a fire, while the poorer ones find warmth under the blanket. On one such evening of rain and freezing cold, the narrator visits the cottage of his old neighbor, Miss Mackenzie, who he finds rolled up under a blanket, basking in the warmth of three hot water bottles. As they chatted, the weather outside deteriorated, and they kept getting distracted by the loud noise of the rain and the incessant sparks of lightning outside. The world outside was dreary. The distant hills just a blurred silhouette against a dark and stormy sky. It was scary and the cold creeping into the room and spreading its claws everywhere added to the gloom and the terror of the night. The narrator kept glancing out of the window every time there was a flash of lightning when suddenly in a flash of ferocious light, the hill on the opposite side of the house was lit and he saw something he had never noticed before. A pile of ruins, sinister, deathly. Miss Mackenzie caught his glance and explained that he was looking at Burnt Hill, where, for some unearthly reason, every dwelling that was built was burnt to the ground by the lightning every time there was a storm. Haunted, she said it was. And went on to reveal the story behind the haunting, a story of lovers with a fault in their stars.

Robert was a young, vibrant, handsome Englishman of around eighteen, born in India, but with plans to return and settle in England, as per his parents' wishes, but all his plans went awry when one day he heard a sweetly melodious singing voice of a girl in the distance. He followed the voice it was enthralling in its beauty and touched the deepest core of 
his young heart. A heart that went spiraling out of control once his eyes fell on the owner of that low, sweet, strange voice. A local girl from the village, she was radiant and beautiful. Robert fell hopelessly and helplessly in love with her. A love-struck heart knows no boundaries, Robert saw no differences between the girl and him: she, the daughter of a Brahmin landlord in the village, and he, an English man. Day after day, he followed her around, captivated by her beauty, hypnotized by her voice. Day after day, he fell more and more in love with her. Eventually, seeing his persistence in following her around and the open admiration on his face, the girl relented. Gone were thoughts of discrimination, fear of lack of communication. They fell in love and dreamt of a future together. Robert lost no time in seeking her father and asking for her hand in marriage... Even in the modern world, it is unconventional. In the pre-independence era, it was unheard of and unthinkable. Encountering the wrath and opposition of parents and knowing that they could never have a happily ever after with parents' consent, they did what desperation made them do. They eloped.

Their plan was good, carefully thought out. They met one dark night at the ruins on the Burnt Hill, from there where to go to the plains and follow their dreams of togetherness. But fate had other plans for them and nature played a spoilsport. As soon as they reached the ruins, the storm started, accompanied by heavy rain, thunder, and lightning. They had probably huddled under the broken ceiling of the ruins in a futile attempt to protect themselves from the ravages of nature. But lightning struck, and the poor, dilapidated ceiling was no protection. No one knows what happened, but early next morning the charred remains of their bodies were found mingled in the ruins. Nature which gives life, nature which gives hope, nature which soothes our souls, put their souls to rest forever. They say that the souls of those who die with unfulfilled desires never leave the earth. And in accordance with this common belief, people on the hills often heard the voices of the star-crossed lovers reverberating in the hills. Two star-crossed lovers whose voices still reverberate in the winds on the hills. Villagers still claim the hills are haunted by the presence of the long-dead lovers. The truth, only the hills knew.

All the spooky stories of Ruskin Bond are set against the background of hills as hills are believed to resonate sounds and indicate less population and traffic. On the lighter side, ghosts also do not like crowds and traffic congestion. He has taken his readers up and across the hills, down the valleys and into thick forests. In all his books, abnormal and supernatural presences seem to reside in thick forests and hills. Heavy gusts of winds make trees hiss and swish, thereby creating the perfect background score for ghosts to travel and reside. And perfect music to instill nail-biting fear in readers irrespective of age. Not to forget the heavy mists rising from the hills much before the setting of dusk, giving the perfect eerie setting. One also often comes across situations in which the main character is driving a car on a humid day with a little overcast on a road which is rarely traveled. This is soon followed up by a downpour accompanied by thunder and lightning.

An extract from A Season of Ghosts reads ..."But I was stalked by the shadows of the trees, by the crooked oak branches reaching out towards me-some threateningly, others as though they needed companionship." This line makes a multi-pronged attack on the psyche of readers. Crooked oak branches can tickle an avid reader's imagination into visualizing the various shapes of branches which can arise in sinister settings and reach out as if to rustle the reader. Use of phrases like stalked by shadows arouses a sense of foreboding as if something is about to happen. And at such a stage, a reader is never able to let go till the finish. Ruskin Bond makes use of all parts of the mountains to tell spellbinding stories of ghosts. Narrow paths on mountains, darkness around, sounds arising from gusts of wind keep the reader enraptured till the end. 
Whispers in the Dark: A Book of Spooks is a notable collection of dark stories from this arch storyteller. Here, he has established the peepal tree as the abode of witches and ghosts, which he calls 'Pisaach' and 'Churel'. This is a belief which happens to be handed over generations, being weaved into stories recited by grandparents and being taught in schools as part of the curriculum.

Spook and nature will not be complete without a special mention of Ruskin Bond's The Wind on the Haunted Hill. A story of three kids - eleven-year-old Usha, her younger brother Suresh and her friend, Binya, a slightly older girl. They live in a village on the slopes of a hill. That there are always strong winds in these parts is clear from the practice of people keeping large stones on their tin roofs, for fear of being blown away. On a windy day, Usha suddenly realizes that she has to go to the market which is three miles away from the village. And very befitting of a ghost story, she had to go alone as Suresh and Binya have other chores to attend to. A prelude to a perfect day is set by reference to blooming of wildflowers and white blossoms, very appropriately accompanied by a happy whistling thrush glistening in the sunshine.

And from here, the unique style of Ruskin Bond's rendition of ghost stories takes off. Usha's conviction that ghosts do not appear during the day is reflective of how darkness is associated with the presence of the preternatural. Very aptly, words have been used to insinuate sounds that children associate with heavy winds due to stories handed over generations. Whoo... Whooo.... Whoooo...... cried the wind as it swept down from the Himalayan snows. The hills are typically described to have a few trees and bushes which are stunted to add to the sinister feeling, not to miss out the ruins of a small settlement. Ghosts have been known to reside in ruins and forests with stunted trees and this has not been overlooked by this stalwart writer in this rendition.

And as the story unfolds, it becomes obvious that all parts of nature have been used to create fear. Usha's return journey starts with her apprehensions which heighten at a very interesting pace, a pace that is set by the author with the vivid support of nature and its vagaries. It ascends with the heavy downpour of rain, along with flashes of lightning and the predictable peals of thunder which are inherent in all ghost stories. The looming ruins add to the sense of foreboding. Amidst winds that just don't blow but howl, the thick foliage of swaying trees thrashes against the ground. Usha seeks temporary shelter in the ruins. The sense of fear caused by the raging storm is doubled when Usha stumbles on to something furry which turns out to be a cat, scuttling away in the darkness.

Something which happens with most of us, we tend to remember stories of the supernatural when we are in situations that are far from normal like the instant situation in the story. Usha starts reminiscing about her grandfather's story about these ruins where two children - a boy and his sister who were killed during the thunderstorm, now play in the moonlight at night. This point in the story marks the fear factor at its peak when, as if to echo Usha's thoughts, a blue light shines accompanied by lightning and thunder, lighting up the opposite wall and Usha sees two small children, crouching in front of the unused fireplace in the ruins. They are the ghosts Usha had heard about and she decides not to stay a minute longer. Usha along with the innumerable readers have experienced this sense of fear mounting up through the story and culminating at this point.

This paper intends to study the effect of nature in creating terror, appeal and spook in stories. And when we speak on this theme, the connection between nature and Ruskin Bond is of special mention. His unique style of rendition makes the reader understand the spirit and character. The ethos in his stories is so reflective of his carefully and aptly chosen words. Situations are made to unravel in different settings at a steady pace to create an atmosphere of dismay and horror. Most of his readers tend to remember these due to the author's rendition and choice of words. 
A veteran like Ruskin Bond had well understood the indisputable and unmatched power of nature around us. He could fathom a long time back that one is able to study and identify with nature first hand, as nature has the power to influence our emotions and actions. We all see evidence of this when we travel through different landscapes and emote differently, be it a desert, beach, mountain or jungle. Even Mary Shelley had used Frankenstein and his trials to show how detrimental, defying nature can be.

Although this paper sets out to indicate the effect of nature on creating spook, Ruskin Bond's stories have showcased the myriad of emotions that nature can arouse in readers. As elucidated above, Listen to the Wind and The Wind on the Haunted Hill is a vivid exemplar of how nature can be both charming and petrifying almost simultaneously.

\section{REFERENCES}

1. Aggrawal, Amita. The Fictional World of Ruskin Bond. Sarup \& Sons Ltd. New Delhi, 2005

2. Bond, Ruskin. Dust on the Mountain: Collected Stories. Penguin Books. New Delhi, 1996

3. Das, Bijay Kr. Critical Essays on Post Colonial Literature. Atlantic Publishers. New Delhi, 2008

4. Siddiqua, Rukhsana. "The Situation Of National Security Of Bangladesh: Explanation In Aspect Of Global And Regional Context Of Bangladesh Terrorism."

5. Glotfelty, Cheryll and Harold Fromm. eds. The Ecocriticism Reader: Landmarks in Literary Ecology. University of Georgia Press. Athens, 1996

6. Sinha M P, Jauhari R, Dave Nigam. Ruskin Bond a critical evaluation. Atlantic Publishers. New Delhi, 2012 
